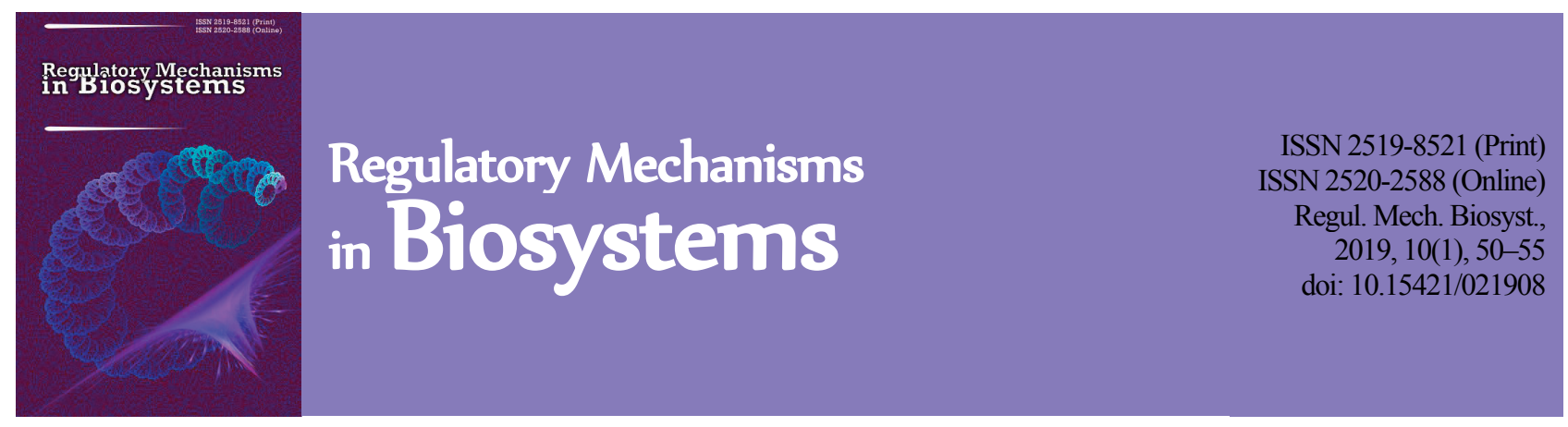

\title{
Impact of polyvinyl chloride, polystyrene, and polyethylene on the organism of mice
}

\author{
M. A. Lieshchova*, V. V. Brygadyrenko*, **, N. M. Tishkina*, P. M. Gavrilin*, A. A. Bohomaz* \\ *Dnipro State Agrarian and Economic University, Dnipro, Ukraine \\ **Oles Honchar Dnipro National University, Dnipro, Ukraine
}

Article info

Received 16.02.2019

Received in revised form 14.03.2019

Accepted 17.03.2019

Dipro State Agrarian and Economic University, Serhii Efremov st., 25, Dnipro, 49600, Ukraine. Tel.: +38-056-268-54-17. E-mail:

lieshchova.m.o@dsau.dp.ua

Oles Honchar Dnipro National University, Gagarin av., 72, Dnipro, 49010, Ukraine. Tel.: +38-050-93-90-788 E-mail:brigad@ua.fm

Lieshchova, M. A., Brygadyrenko, V. V., Tishkina, N. M., Gavrilin, P. M., \& Bohomaz, A. A. (2019). Impact of polyvinyl chloride, polystyrene, and polyethylene on the organism of mice. Regulatory Mechanisms in Biosystems, 10(1), 50-55. doi:10.15421/021908

Goods of plastic, due to their durability, universality and economical properties are broadly used in all spheres of life. On the whole, polymers are inert and nontoxic, but in the process of their production, various additives are used, which on contact or introduction into an organism has a negative effect on it. In our study, we determined the impact of some types of plastic (polyvinyl chloride, polysterene and polyethylene) on the organism of laboratory animals according to changes in their body weight, indices of mass of the internal organs, and blood parameters. For the experiment, we formed four groups of white male mice at the age of 3 weeks and average body weight of $50 \mathrm{~g}$. For each group, we used different litter. For group I, the litter was sawdust; and for the other groups we added plastic products in different volumes to the sawdust; for group II finely cut polyvinyl chloride, for group III cut polyethylene, and for group IV granules of polystyrene. Every 3 days, we determined the body weight of the animals, and 32 days later we determined mass of the organs, clinical and biochemical parameters of the blood. Addition of polyvinyl chloride, polyethylene, and polystyrene into the substrate for mice did not have a significant effect on tempi of growth of body weight, and also relative mass of heart and lungs. Polyvinyl chloride and polystyrene have an immune-suppressive effect, and polyvinyl chloride affects both central and peripheral organs, and polystyrene mostly harms the peripheral organs. All used types of plastic cause leukocytopenia, following which neutrophilia of band neutrophils and monocytosis takes place as a result of damage to the biological barriers. We determined the systemic toxic effect of the studied types of plastic on the internal organs, which manifested in increase in their mass (liver, kidneys), steep increase in the activity of liver enzymes (AST, ALT), simultaneous decrease in activity of alkaline phosphatase and content of cholysterol and glucose in the blood serum of the mice. Also polyvinyl chlorine, polyethylene and polystyrene cause degeneration of the epithelium of the uriniferous tubule, which is manifested in reduction of globulins and creatinine in the blood of animals from the experimental groups following increase in relative mass of the kidneys. The results of our research allow us to state that different types of plastic can cause toxic effect on animals, as well as people who are in frequent contact with them.

Keywords: health effects; plastics; polyvinyl chloride; polystyrene; polyethylene; cholesterol; biochemical parameters of blood; relative mass of the organ.

\section{Introduction}

Plastic is a collective term which stands for material based on natural, semi-synthetic and synthetic highly-molecular compounds. These substances are mostly made of carbon, hydrogen, oxygen and nitrogen. Currently, the most popular plastic is the one made on the base of synthetic polymers, which due to its durability is used in all spheres of production. Plastic and plastic goods are integrated into everyone's life. None of the industries can function without goods made of plastic. They are universal and economical due to their durability, simplicity in processing and light weight (Andrady \& Neal, 2009). For their production, less energy is needed than for producing alternative materials such as metal or glass. As of 2018, $380 \mathrm{M}$ tons of plastic was produced around the world, and $8 \%$ of the total amount of extracted oil was used for its production. Around two thirds of global production of plastic comprises mass products: polyethylene, polyvinyl chloride and polysterene. The main spheres of their use are construction, packaging, machine-building, electronics, transport and medicine (Zahra et al., 2018). The reasons for their broad distribution are mainly relatively low cost and simplicity in processing and then their properties, which in many ways are not inferior to the qualities of more expensive special substances (Andrady \& Neal, 2009; Dudnik et al., 2017).
Polyethylene is characterized by high chemical stability, does not dissolve in alkalines and acids, and has no smell and taste. It is one of the most widely distributed plastics in the world, the total amount produced globally in 2008 being about $80 \mathrm{M}$ tons (Piringer \& Baner, 2008). It is used for making materials for packaging - film, plastic bags, containers (bottles, canisters, etc). Furthermore, it is used for making tubes, as an isolative material and in the electrotechnical and radioelectric industries, in making cables, and as material for hydroisolation. Polyethylene is one of the cheapest and biologically safest materials, therefore it is broadly used in medicine and housing construction.

Polyvinyl chloride (PVC) is highly dense, chemically resistant to acids and alkalines and has good dielectric properties. It is broadly used in production of packaging for food, plastic film, containers, cosmetics, rubber protection for goods for children, water pipes and hoses, automobile upholstery, and also medicine (Chiellini et al., 2013).

Polystyrene is a transparent, quite fragile polymer which does not withstand high temperatures (up to $80^{\circ} \mathrm{C}$ ). A number of goods are produced from polystyrene, which are used in domestic activities (disposable plates, packaging, toys for children, etc.), and also in construction, in goods for medicine (parts for blood transfusion system, Petri dishes, additional disposable instruments). In pure state these polymers are inert and non-toxic, but in the process of their production, harmful stabilizers, 
salts of heavy metals and other technical additives are used, which negatively affect the human organism of after being introduced to it (Halden, 2010; Lamontagne, 2012; Norh \& Halden, 2013; Boyko \& Brygadyrenko, 2017; Lieshchova et al., 2018). Apart from the problem of safety in the process of production, many chemical additives which provide needed properties for the produced goods also negatively affect the ecological situation and human health (Anon, 2007; Koch \& Calafat, 2009). The most broadly used additives are phthalates - salts and ethers of phthalic (ortho-phthalic) acid. They are toxic, can cause serious diseases of the nervous and cardiovascular systems. There are also reasons to belive that phthalates have a carcinogenic effect and cause cancer, which is why they are prohibited in the countries of the EU and in the USA for use in making toys for children. Formaldehyde (methanol, or formic aldehyde) is extremely toxic, affects the nervous and respiratory systems, negatively affects the reproductive system and can cause genetic disorders in progeny. Also, under prolnged contact, it has a carcinogenic effect. Styrenes (phenylethylene, vinylbenzene) are low-toxic, but affect mucous membranes. According to a number of authors, they have carcinogenic properties, can act as chemical estrogens, which have a negative effects on reproductive functions. Vinyl chloride is an organic substance which is the simplest chlorinated ethylene. It is toxic, affects the central nervous system, skeletal system, brain, heart, liver, causes systemic disorders in the connective tissues, inhibits the immune system. Vinyl chloride has carcinogenic, mutagenic and teratogenic effects. Bisphenol Adiphenylpropane is similar to estrogens, leads to infertility in men and women, inhibits functions of the endocrine system, leads to disorder of the development of the brain in children, causes development of cardiovascular pathologies (Al-Khatim \& Ali, 2006; Singh \& Li, 2012; Posnack, 2014). All these substances are additional, they are present in one or another type of plastic, and due to them, the needed consumer properties are obtained (flexibility, strength, thermoresistance, etc).

Up to $80 \%$ of "plastic" substances found in the human organism are introduced from materials used in construction and finishing (from plastic windows, furniture), but most often - from tableware. Polymers themselves are inert and non-toxic, but technogenic additives, solvents, products of chemical decomposition, after penetration into food can have a toxic effect (Halden, 2010; Lamontagne, 2012; Norh \& Halden, 2013). This can occur in storage or heating of food When they have outlived their usefulness (become old), these materials produce toxic products. This situation is complicated by incorrect or repeated use of disposable tableware, which leads to migration of toxic substances into food. Technogenic and food plastic is most often made out of polyvinyl chloride (PVC), polypropylene, polyethylene, polystyrene and polycarbonate. Examples of contamination of food products with plastic have been recorded for most types of plastic, including styrene from polystyrene, plastifiers of PVC, antioxidants of polyethylene and acetaldehyde of polyethylene terephthalate.

Despite ubiquitous use, plastic goods can harm not only humans, but also vertebrate animals which live near the landfills of solid municipal wastes. From 1950 to 2018, around 6.3 billion tons of plastic were produced globally, out of which $9 \%$ were recycled and $12 \%$ burnt. A large amount of plastic waste has inevitably become introduced to the environment, and the researchers presume that $90 \%$ of seabirds have plastic in their bodies (Derraik, 2002).

It can release harmful chemical substances into the soil, which can later penetrate ground water or the nearest sources of water and thus have a negative effects on the organisms of animals and humans (Halden, 2010; Niaounakis, 2017). Plastic is one of the components of marine debris. In large amounts it becomes introduced into marine and oceanic debris in the form of microplastics. Plastic waste make up about $10 \%$ of beach surface around the world. In oceans, plastic usually decomposes in the course of a year, but not completely, and during this process, toxic chemical elements, such as bisphenol A and polystyrene can become introduced into water from some forms of plastic (Knight, 2012). Particles of polysterene are the most common types of plastic pollution in oceans, and combined with polyethylene films, plastic bags and containers for food products make up the largest part of oceanic debris (Knight, 2012). According to assessments made in 2014, 268,940 tons of plastic are present on the ocean surface, and the total amount of separate fragments of plastic waste equal 5.25 trillions (Eriksen et al., 2014). Over 400 thou- sand marine mammals die every year as a result of plastic pollution in the ocean. More than 260 species of animals, including invertebrates, either accidentally swallow plastic or become trapped in plastic, which later in one or the other way leads to their death (Landon-Lane, 2018).

Therefore the objective of this article was to determine the impact of polyvinyl chloride, polystyrene and polyethylene on the changes in body weight, index of mass of the organs and biochemical parameters of blood in mice in the conditions of laboratory experiment.

\section{Materials and methods}

The protocol of the studies was agreed with the local ethics committee of the Dnipro State Agro-Economic University. A total of 24 male 3 week old mice with average weight of $50 \mathrm{~g}$ were used in the experiment. The animals were kept in a vivarium of the Dnipro State Agro-Economic University. The conditions of maintenance and feeding were standard. The temperature of the room was $20-22{ }^{\circ} \mathrm{C}$. The mice were fed twice a day (in the morning and evening) with a diet balanced according to all main parameters, and had free access to water. For the experiment, different litter was given for the animals in each group. In the control group I, the litter for the mice was sawdust, and in the groups II-IV - mixed litter. In the group II, the litter was in equal proportions mixed with finely cut polyvinyl chloride, in III group - cut polyethylene, and in group IV - granules of polystyrene. The experiment lasted 32 days. During the experiment, every three days, the animals were weighed using the method of direct weighing with $0.01 \mathrm{~g}$ accuracy and the litter was changed. For mortification of animals, we used ether for narcosis, putting the animals into a state of deep sleep according to the European Convention for the Protection of Vertebrate Animals used for Experimental and Other Scientific Purposes (Strasbourg, 1986; Kyiv, 2001) and following the requirements of the Law of Ukraine №3447-IV of 21.02.2006 "On protection of animals from cruel treatment". The blood was taken from the carotid artery by decapitation of animals for the following biochemical and morphological examinations. Biochemical studies of blood included: determining total protein using the biuret method, and globulins and protein coefficient - by calculation, and albumins - according to reaction with bromocresol green. For determining the activity of aspartate aminotransferase (AST) and alanine aminotransferase (ALT), we used kinetic method based on the optic Warburg test, alkaline phosphatase - enzymic with n-nitrophenylphosphate, and glucose - glucose oxidase method. We determined total bilirubin and uric acid - enzymically with uricase using automatic biochemical analyzer Miura 200 (Italy) and sets of reagents High Technology (USA), PZ Cormay S.A. (Poland) and Spinreact S.A. (Spain). Determination of the number of erythrocytes and leukocytes in stabilized blood of mice was performed in BC-2800Vet and Mindray automatic hematological analyzers. For the leukogram, we prepared blood smears according to Pappenheim followed by staining according to the Romanowsky-Giemsa method.

For the futher stages of the research, using anatomic dissection, the internal organs were taken out of the white mice (the heart, liver, lungs, kidneys, spleen, and the thymus). We determined their absolute mass by weighing using KERN-440-35A scales with accuracy up to $0.001 \mathrm{~g}$ followed by determintion of the index of mass of the organs. Analysis of the data was made using Statistica 6.0 (StatSoft Inc., USA) program. The data are presented in tables as $\mathrm{x} \pm \mathrm{SD}(\mathrm{x} \pm$ standard deviation). Differences between the values in the control and experimental groups were determined using the Tukey test, where the differences were considered reliable at $\mathrm{P}<0.05$ (taking into account the Bonferroni correction).

\section{Results}

No reliable changes were observed in tempi of growth of the mice's body weight in different variants of the experiment (Table 1). In the variant of the experiment where polyvinyl chloride was added to the litter, three out of six animals were observed to have body weight significantly reduced, as a result of which the average body weight in this group remained practically with no changes. Addition of the studied polymers to the litter substrate of the mice had no effect on the relative mass of the 
heart and lungs (Table 2). Addition of polystyrene to the substrate reliably increased the mass index of the liver by $23.9 \%\left(\mathrm{~F}=16.27, \mathrm{~F}_{0.00833}=\right.$ $10.74 ; \mathrm{P}=2.4 \cdot 10^{-3}$ ). Addition of polyvinyl chloride to the substrate caused reduction of relative mass of the thymus by $35.5 \%(\mathrm{~F}=21.45$, $\left.\mathrm{F}_{0.00833}=10.74 ; \mathrm{P}=9.3 \cdot 10^{-4}\right)$. The spleen had a tendency towards decrease in relative mass by $38.6 \%\left(\mathrm{~F}=8.95, \mathrm{~F}_{0.00833}=10.74 ; \mathrm{P}=0.013\right)$ in the variant of the experiment with polystyrene (Table 2). Relative mass of the right kidney increased $\left(\mathrm{F}=12.36, \mathrm{~F}_{0.00833}=10.74 ; \mathrm{P}=5.6 \cdot 10^{-3}\right)$ in the variant with polyvinyl chloride by $23.3 \%$ and by $30.4 \%$ in the variant with polystyrene $\left(\mathrm{F}=19.60, \mathrm{~F}_{0.00833}=10.74 ; \mathrm{P}=1.3 \cdot 10^{-3}\right)$. Relative mass of the left kidney in the same variants of the experiment increased at the level of tendency by $19.7 \%\left(\mathrm{~F}=9.28, \mathrm{~F}_{0.00833}=10.74 ; \mathrm{P}=0.012\right)$ and $19.6 \%\left(\mathrm{~F}=6.08, \mathrm{~F}_{0.00833}=10.74 ; \mathrm{P}=0.033\right)$ respectively (Table 2$)$.

\section{Table 1}

Changes in body weight ( $\mathrm{g} / 24$ hours) of male mice exposed to addition to their litter substrate of polyvinyl chloride, polystyrene and polyethylene $(\mathrm{x} \pm \mathrm{SD}, \mathrm{n}=6)$

\begin{tabular}{lcccc}
\hline \multicolumn{1}{c}{ Group } & $\begin{array}{c}\text { Average daily increase in } \\
\text { animals body weight, } \mathrm{g} / \text { day }\end{array}$ & $\begin{array}{c}\text { In relation } \\
\text { to control, \% }\end{array}$ & $\mathrm{F}\left(\right.$ at $\mathrm{F}_{0.05}=$ & 9.01) \\
\hline Control & $0.128 \pm 0.050$ & - & - & - \\
\hline Polyvinyl chloride & $-0.012 \pm 0.149$ & -9.2 & 4.71 & 0.062 \\
\hline Polystyrene & $0.093 \pm 0.090$ & 72.7 & 0.69 & 0.426 \\
\hline Polyethylene & $0.071 \pm 0.063$ & 55.9 & 2.92 & 0.117 \\
\hline
\end{tabular}

Addition of polyvinyl chloride, polystyrene and polyethylene into the substrate for mice did not reliably change content of urea and nonorganic phosphorus in blood of the mice. Content of total bilirubin in the blood of mice exposed to polyvinyl chloride increased 2.2 times $(\mathrm{F}=$ 64.10, $\left.\mathrm{F}_{0.00833}=10.74 ; \mathrm{P}=2.3 \cdot 10^{-5}\right)$. Content of total protein and the De Ritis Ratio reliably changed when polystyrene and polyethylene were present in the litter for mice (Table 3). All the other examined biochemical characteristics of blood reliably changed compared to the the control under the impact of any of the studied types of polymers. Content of albumins increased by $45.0-69.2 \%$, and content of globulins decreased to $53.1-80.4 \%$ compared to the control values. Protein coefficient increased to $214.9-283.6 \%$ compared the control (Table 3) with mice exposed to the studied types of polymers. Activity of aspartate aminotransferase (AST) increased to 237.8-305.4\%, and alanine aminotransferase (ALT) to $167.4-251.6 \%$ compared to the control group. By contrast, activity of alkaline phosphatase decreased to $35.2-59.5 \%$ compared to the control group (Table 3). Addition of the studied polymers to the substrate where the mice lived caused a practically two-fold reduction of the concentration of glucose and cholesterol in their blood: to $41.8-53.6 \%$ and 47.9 $61.8 \%$ compared to the control group.

Hematocrit, hemoglobin mass in erythrocyte, percent of basophils, eosinophils, myelocytes, lymphocytes, young and segmented-nuclei neutrophils of male mice remained unchanged under the impact of addition of polyvinyl chloride, polystyrene and polyethylene to the substrate (Table 4). When the studied polymers were added to the animals' substrate, the hemoglobin content per unit of blood volume decreased to $77.1-86.2 \%$ of the values of the control group, although this was within the physiological norm. The number of erythrocytes per unit of blood volume of blood decreased more significantly with addition of polystyrene and polyethylene to the substrate (59.3\% and $62.9 \%$ respectively), though polyvinyl chloride also caused reduction (to $68.8 \%$ compared to the level of the control group) in this characteristic (Table 4). Unlike the number of erythrocytes, their volume and average concentration of hemoglobin in them reliably increased to $153.3-167.9 \%$ compared to the control. This caused reliable increase in the colour indicator in all three variants of the experiment to $125.9-130.2 \%$ compared to the control. The number of leukocytes decreased below the norm in the variant of the experiment with with polystyrene and polyethylene (to $22.6 \%$ and $37.3 \%$ compared to the control group of animals). Addition of polyvinyl chloride to the animals' litter caused steep decrease in the norm of the content of thrombocytes in two experimental animals; the level of thrombocytes in the other studied groups did not change (Table 4).

\section{Table 2}

Change in relative mass of the organs (\%) of male mice under the impact of adding polyvinyl chloride, polystyrene and polyethylene to litter substrate ( $x \pm \mathrm{SD}, \mathrm{n}=6$, duration of experiment -32 days)

\begin{tabular}{|c|c|c|c|c|c|c|c|}
\hline Organ & Control & Polyvinyl chloride & $\begin{array}{l}\text { Polyvinyl chloride } \\
\text { compared to the } \\
\text { control, } \%\end{array}$ & Polyethylene & $\begin{array}{l}\text { Polyethylene } \\
\text { compared to the } \\
\text { control, } \% \\
\end{array}$ & Polystyrene & $\begin{array}{c}\text { Polystyrene } \\
\text { compared to the } \\
\text { control, } \% \\
\end{array}$ \\
\hline Heart & $0.671 \pm 0.100^{\mathrm{a}}$ & $0.530 \pm 0.082^{\mathrm{a}}$ & 79.0 & $0.552 \pm 0.066^{\mathrm{a}}$ & 82.2 & $0.614 \pm 0.062^{\mathrm{a}}$ & 91.5 \\
\hline Liver & $5.461 \pm 0.489^{\mathrm{a}}$ & $5.250 \pm 0.240^{\mathrm{a}}$ & 96.1 & $5.550 \pm 0.427^{\mathrm{a}}$ & 101.6 & $6.767 \pm 0.625^{\mathrm{b}}$ & 123.9 \\
\hline Lungs & $0.706 \pm 0.048^{\mathrm{a}}$ & $0.716 \pm 0.075^{\mathrm{a}}$ & 101.4 & $0.769 \pm 0.100^{\mathrm{a}}$ & 108.9 & $0.877 \pm 0.157^{\mathrm{a}}$ & 124.2 \\
\hline Thymus & $0.371 \pm 0.056^{\mathrm{a}}$ & $0.240 \pm 0.042^{\mathrm{b}}$ & 64.5 & $0.319 \pm 0.141^{\mathrm{ab}}$ & 86.2 & $0.317 \pm 0.210^{\mathrm{ab}}$ & 85.4 \\
\hline Spleen & $0.336 \pm 0.049^{\mathrm{a}}$ & $0.329 \pm 0.053^{\mathrm{a}}$ & 98.1 & $0.258 \pm 0.096^{\mathrm{a}}$ & 76.8 & $0.206 \pm 0.094^{\mathrm{a}}$ & 61.4 \\
\hline Right kidney & $0.690 \pm 0.086^{\mathrm{a}}$ & $0.849 \pm 0.071^{\mathrm{b}}$ & 123.3 & $0.770 \pm 0.126^{\mathrm{ab}}$ & 111.7 & $0.899 \pm 0.078^{b}$ & 130.4 \\
\hline Left kidney & $0.698 \pm 0.092^{\mathrm{a}}$ & $0.836 \pm 0.062^{\mathrm{a}}$ & 119.7 & $0.774 \pm 0.119^{\mathrm{a}}$ & 110.9 & $0.835 \pm 0.099^{\mathrm{a}}$ & 119.6 \\
\hline
\end{tabular}

Note: different letters indicate values which reliably differed one from another within one line of table according to the results of comparison using Tukey test with Bonferroni correction.

\section{Table 3}

Change in biochemical parameters of blood of males of mice under effect of addition of polyvinyl chloride, polystyrene and polyethylene to the litter substrate $(\mathrm{x} \pm \mathrm{SD}, \mathrm{n}=6$, duration of experiment -32 days)

\begin{tabular}{|c|c|c|c|c|c|c|c|}
\hline Parameters & Control & $\begin{array}{l}\text { Polyvinyl } \\
\text { chloride }\end{array}$ & $\begin{array}{l}\text { Polyvinyl chloride } \\
\text { compared to the } \\
\text { control, } \%\end{array}$ & Polyethylene & $\begin{array}{l}\text { Polyethylene } \\
\text { compared to the } \\
\text { control, } \% \\
\end{array}$ & Polystyrene & $\begin{array}{c}\text { Polystyrene } \\
\text { compared to the } \\
\text { control, } \%\end{array}$ \\
\hline Total protein, $\mathrm{g} / \mathrm{L}$ & $54.0 \pm 2.4^{\mathrm{a}}$ & $58.2 \pm 5.5^{\mathrm{a}}$ & 107.8 & $44.5 \pm 4.6^{b}$ & 82.4 & $41.0 \pm 3.7^{b}$ & 75.9 \\
\hline Albumins, $\mathrm{g} / \mathrm{L}$ & $16.7 \pm 1.2^{\mathrm{a}}$ & $28.2 \pm 2.8^{b}$ & 169.2 & $24.7 \pm 2.3^{\mathrm{b}}$ & 148.0 & $24.2 \pm 1.9^{b}$ & 145.0 \\
\hline Globulins, g/L & $37.3 \pm 2.9^{\mathrm{a}}$ & $30.0 \pm 3.7^{b}$ & 80.4 & $19.8 \pm 3.3^{\mathrm{c}}$ & 53.1 & $22.2 \pm 4.2^{\mathrm{c}}$ & 59.4 \\
\hline Protein coefficient, $\mathrm{U}$ & $0.45 \pm 0.06^{\mathrm{a}}$ & $0.96 \pm 0.11^{\mathrm{b}}$ & 214.9 & $1.27 \pm 0.22^{\mathrm{b}}$ & 283.6 & $1.12 \pm 0.28^{\mathrm{b}}$ & 250.0 \\
\hline Urea, mmol/L & $12.5 \pm 3.8^{\mathrm{a}}$ & $11.7 \pm 1.3^{\mathrm{a}}$ & 93.3 & $12.1 \pm 0.4^{\mathrm{a}}$ & 96.8 & $10.8 \pm 1.5^{\mathrm{a}}$ & 86.6 \\
\hline Creatinine, $\mu \mathrm{mol} / \mathrm{L}$ & $21.7 \pm 2.5^{\mathrm{a}}$ & $72.4 \pm 14.9^{\mathrm{b}}$ & 333.6 & $53.3 \pm 10.9^{\mathrm{b}}$ & 245.8 & $41.7 \pm 9.1^{\mathrm{b}}$ & 192.0 \\
\hline AST, U/L & $116.5 \pm 5.7^{\mathrm{a}}$ & $277.0 \pm 133.2^{\mathrm{b}}$ & 237.8 & $355.8 \pm 44.2^{\mathrm{b}}$ & 305.4 & $302.5 \pm 71.8^{b}$ & 259.7 \\
\hline ALT, U/L & $56.8 \pm 10.1^{\mathrm{a}}$ & $143.0 \pm 69.1^{b}$ & 251.6 & $117.0 \pm 20.0^{b}$ & 205.9 & $95.2 \pm 24.7^{\mathrm{b}}$ & 167.4 \\
\hline De Ritis Ratio (AST/ALT), U & $2.12 \pm 0.35^{\mathrm{a}}$ & $2.56 \pm 1.30^{\mathrm{ab}}$ & 120.9 & $3.08 \pm 0.40^{\mathrm{b}}$ & 145.7 & $3.20 \pm 0.39^{b}$ & 151.2 \\
\hline Alkaline phosphatase, $\mathrm{U} / \mathrm{L}$ & $65.2 \pm 7.5^{\mathrm{a}}$ & $23.0 \pm 10.4^{\mathrm{b}}$ & 35.2 & $35.2 \pm 9.6^{\mathrm{b}}$ & 54.0 & $38.8 \pm 3.3^{\mathrm{b}}$ & 59.5 \\
\hline Total bilirubin, $\mu \mathrm{mol} / \mathrm{L}$ & $6.94 \pm 0.13^{\mathrm{a}}$ & $15.56 \pm 2.66^{b}$ & 224.1 & $8.90 \pm 2.54^{\mathrm{a}}$ & 128.2 & $7.68 \pm 2.56^{\mathrm{a}}$ & 110.7 \\
\hline Glucose, $\mathrm{mmol} / \mathrm{L}$ & $8.73 \pm 0.50^{\mathrm{a}}$ & $4.04 \pm 1.24^{\mathrm{b}}$ & 46.3 & $3.65 \pm 0.79^{b}$ & 41.8 & $4.68 \pm 0.75^{\mathrm{b}}$ & 53.6 \\
\hline Non-organic phosphorus, $\mathrm{mmol} / \mathrm{L}$ & $2.49 \pm 0.52^{\mathrm{a}}$ & $3.08 \pm 0.58^{\mathrm{a}}$ & 123.7 & $2.43 \pm 0.37^{\mathrm{a}}$ & 97.7 & $2.22 \pm 0.39^{\mathrm{a}}$ & 89.0 \\
\hline Cholestyrol, $\mathrm{mmol} / \mathrm{L}$ & $2.78 \pm 0.33^{\mathrm{a}}$ & $1.72 \pm 0.08^{\mathrm{b}}$ & 61.8 & $1.33 \pm 0.20^{\mathrm{b}}$ & 47.9 & $1.55 \pm 0.15^{\mathrm{b}}$ & 55.7 \\
\hline
\end{tabular}

Note: see Table 1. 
Table 4

Change in general analysis of blood and leukogramm of male mice under the impact of adding polyvinyl chloride, polystyrene and polyethylene to litter substrate $(x \pm S D, n=6$, duration of the experiment -32 days)

\begin{tabular}{|c|c|c|c|c|c|c|c|}
\hline Parameter & Control & $\begin{array}{l}\text { Polyvinyl } \\
\text { chloride }\end{array}$ & $\begin{array}{l}\text { Polyvinyl chloride } \\
\text { compared to the } \\
\text { control, } \%\end{array}$ & Polyethylene & $\begin{array}{l}\text { Polyethylene } \\
\text { compared to the } \\
\text { control, } \%\end{array}$ & Polystyrene & $\begin{array}{c}\text { Polystyrene } \\
\text { compared to the } \\
\text { control, } \%\end{array}$ \\
\hline Hemoglobin, g/L & $154 \pm 11^{\mathrm{a}}$ & $133 \pm 7^{b}$ & 86.2 & $123 \pm 11^{b}$ & 79.5 & $119 \pm 16^{b}$ & 77.1 \\
\hline Hematocrit, $\%$ & $43.5 \pm 2.7^{\mathrm{a}}$ & $45.9 \pm 1.5^{\mathrm{a}}$ & 105.5 & $43.6 \pm 2.5^{\mathrm{a}}$ & 100.3 & $41.9 \pm 5.5^{\mathrm{a}}$ & 96.2 \\
\hline Erythrocytes, $10^{12} / \mathrm{L}$ & $9.12 \pm 0.37^{\mathrm{a}}$ & $6.27 \pm 0.18^{b}$ & 68.8 & $5.74 \pm 0.24^{\mathrm{c}}$ & 62.9 & $5.40 \pm 0.68^{c}$ & 59.3 \\
\hline $\begin{array}{l}\text { Volume of erythrocyte, } \mathrm{MCV} \text {, } \\
\mathrm{fL}\left(10^{-15} \mathrm{~L}\right)\end{array}$ & $47.8 \pm 3.3^{\mathrm{a}}$ & $73.2 \pm 3.8^{\mathrm{b}}$ & 153.3 & $76.0 \pm 1.9^{b}$ & 159.2 & $77.5 \pm 0.8^{b}$ & 162.2 \\
\hline $\begin{array}{l}\text { Mass of hemoglobin in } \\
\text { erythrocyte, } \mathrm{MCH}, \mathrm{pg}\left(10^{-12} \mathrm{~g}\right)\end{array}$ & $22.4 \pm 1.5^{\mathrm{a}}$ & $21.2 \pm 1.0^{\mathrm{a}}$ & 94.8 & $21.4 \pm 1.5^{\mathrm{a}}$ & 95.5 & $22.0 \pm 0.3^{\mathrm{a}}$ & 98.4 \\
\hline $\begin{array}{l}\text { Average concentration of hemo- } \\
\text { globin in erythrocyte, } \mathrm{MCHC}\end{array}$ & $17.0 \pm 1.4^{\mathrm{a}}$ & $28.5 \pm 0.8^{b}$ & 167.9 & $28.1 \pm 1.6^{\mathrm{b}}$ & 165.8 & $28.4 \pm 0.3^{b}$ & 167.6 \\
\hline Colour indicator, $\mathrm{U}$ & $0.508 \pm 0.041^{\mathrm{a}}$ & $0.644 \pm 0.031^{\mathrm{b}}$ & 126.7 & $0.640 \pm 0.046^{\mathrm{b}}$ & 125.9 & $0.662 \pm 0.001^{\mathrm{b}}$ & 130.2 \\
\hline Leukocytes, $10^{9} / \mathrm{L}$ & $11.27 \pm 2.04^{\mathrm{a}}$ & $9.06 \pm 2.10^{\mathrm{a}}$ & 80.4 & $4.20 \pm 1.11^{\mathrm{b}}$ & 37.3 & $2.55 \pm 0.52^{\mathrm{c}}$ & 22.6 \\
\hline Thrombocytes, $10^{9} / \mathrm{L}$ & $278 \pm 81^{\mathrm{a}}$ & $359 \pm 255^{\mathrm{a}}$ & 129.4 & $262 \pm 48^{\mathrm{a}}$ & 94.3 & $220 \pm 80^{\mathrm{a}}$ & 79.3 \\
\hline \multicolumn{8}{|l|}{ Leukocytic formula } \\
\hline Basophils, \% & $0^{\mathrm{a}}$ & $0^{\mathrm{a}}$ & - & $0^{\mathrm{a}}$ & - & $0^{\mathrm{a}}$ & - \\
\hline Eosinophils, \% & $0^{\mathrm{a}}$ & $0^{\mathrm{a}}$ & - & $0^{\mathrm{a}}$ & - & $0^{\mathrm{a}}$ & - \\
\hline $\begin{array}{l}\text { Neutrophils, \% } \\
\text { myelocytes }\end{array}$ & $0^{\mathrm{a}}$ & $0^{\mathrm{a}}$ & - & $0^{\mathrm{a}}$ & - & $0^{\mathrm{a}}$ & - \\
\hline - young & $0^{\mathrm{a}}$ & $0^{\mathrm{a}}$ & - & $0^{\mathrm{a}}$ & - & $0^{\mathrm{a}}$ & - \\
\hline - band & $0.67 \pm 0.82^{\mathrm{a}}$ & $3.60 \pm 1.14^{\mathrm{b}}$ & 540.0 & $6.33 \pm 6.09^{b}$ & 950.0 & $2.83 \pm 0.98^{\mathrm{b}}$ & 425.0 \\
\hline - with segmented nuclei & $24.3 \pm 8.6^{\mathrm{a}}$ & $16.2 \pm 4.9^{\mathrm{a}}$ & 66.6 & $26.3 \pm 13.1^{\mathrm{a}}$ & 108.2 & $23.8 \pm 8.9^{\mathrm{a}}$ & 97.9 \\
\hline Lymphocytes, \% & $74.5 \pm 8.5^{\mathrm{a}}$ & $75.6 \pm 5.3^{\mathrm{a}}$ & 101.5 & $60.3 \pm 15.9^{\mathrm{a}}$ & 81.0 & $66.8 \pm 9.7^{\mathrm{a}}$ & 89.7 \\
\hline Monocytes, $\%$ & $0.40 \pm 0.55^{\mathrm{a}}$ & $4.75 \pm 0.96^{\mathrm{a}}$ & 1187.5 & $6.80 \pm 2.39^{\mathrm{a}}$ & 1700.0 & $6.80 \pm 1.64^{\mathrm{a}}$ & 1700.0 \\
\hline
\end{tabular}

Note: see Table 1.

Addition of the studied polymers to the animals' litter was accompanied by a reliable increase in the proportion of band neutrophils in the three experimental groups, though 16 of 18 animals were still within the physiological norm for this parameter. It should be noted that we observed a significant (by 11.8-17.0 times) increase in the share of monocytes in the leukocytic formula of all three experimental groups of animals, which exceeded the threshold of the physiological norm of this parameter.

\section{Discussion}

Plastic and substances which it contains, particularly bisphenol A and phthalates, broadly used in medicine and the food industry have an estrogenic effect on the organism. This causes serious endocrine disorders and diseases of the reproductive system, associated with them (diseases of the prostate gland, endometritis, and diseases of the ovaries) (Vandenberg et al., 2009). The influence of bisphenol A on the organism is assessed according to its free, conjugative and total content in the blood serum and urine. Bound bisphenol $\mathrm{A}$ in the blood and tissues of humans is at the level of 0.1-10.0 $\mu \mathrm{g}$ (Ikezuki et al., 2002). In the same amount, it was found in amniotic fluid (Yamada et al., 2002), in smaller concentrations in breast milk (Sun et al., 2004), and in $0.46 \mu \mathrm{g} / \mathrm{L}$ concentration in human colostrum (Kuruto-Niwa et al., 2007). Numerous studies on animals have revealed its negative impact on the organism, which is mostly related to the estrogenic properties of this molecule. Depending on the dose, it can cause premature pubescence, change in the level of luteinizing hormone in blood plasm, reduction of testosterone, increase in the size of the prostate, disorders in spermatogenesis and fertility of males; in females, disorders observed include stimulation of the development of the mammary gland, disorders in ovogenesis, increase in embryonic mortality, disorders of the estral cycle, etc. Changes in behaviour have also been observed: hyperactivity, heightened aggressiveness, disorder in trainability, change in response to pain and stress (Vom Saal \& Hughes, 2005; Halden, 2010). The carcenogenic effect of bisphenol A is associated with risk of the development of cancer of the prostate in males and cancer of the mammary gland of female rodents (Ho et al., 2006; Prins et al., 2008; Vandenberg et al., 2009).

Bisphenol A in the composition of plastic harms hemostasis of glucose in the skeletal muscles, causing disorders in its metabolism in the organism in general due to its harmful impact on signal molecules of insulin and translocation of GLUT4 (Mullainadhan et al., 2017). Ecologically significant doses of bisphenol A have a great impact on the endocrine function of the pancreas, affecting $\beta$-cells, as a result of which content and secretion of pancreas insulin increases; this contributes to the development of hyperinsulinemia after intake of food and resistance to insulin in male mice. This substance affects the transmission of signal of insulin on the oxidation of glucose in liver of male rats (Indumathi et al., 2013; Jayashree et al., 2013). Our studies revealed that addition of any of the examined types of plastic to the substrate where mice live causes a practically two-fold reduction of the concentration of glucose in their blood to $41.8-53.6 \%$ compared to the control group.

Polyvinyl chloride often contains phthalates added as plastifiers for flexibility of goods. Due to the property of leaching, phthalates can penetrate into the organisms of human and animals. Despite their quick metabolism (period of half-disintegration lasts from several hours to several days), a certain amount of them is constantly present in the organism (Silva et al., 2004; Frederiksen et al., 2007; Stahlhut et al., 2007). Currently, the influence of phthalates in the organism and risks for health are being studied and the significance of their effect remains an object of discussion. Among the commonest and most unfavourable consequences for health are reproductive dysfunctions, including disgenesis of the testicles, genital anomalies, non-typical characteristics of sperm, up to development of cancer of the gonads (Skakkebæk et al., 2001; Foster, 2006). A positive relationship was found between the increase in the level of phthalates and roundness of the waist, and a converse relationship between the level of phthalates and resistance to insulin (Stahlhut et al., 2007). There are also reports about the influence of phthalates on the function of the human thyroid gland and immune system (Sathyanarayana, 2008). One of the types of phthalates (di(2-ethylhexyl) phthalate, or DEHP) causes increase in the weight of the liver, morphological and biochemical changes in it; it changes the activity of the main enzymes which metabolize medical substances and ethanol, mostly by inhibiting them (Seth, 1982; Chen et al., 2016; Liu et al., 2016). Increase of DEHP dose over 30 days caused changes in urine, which indicate the impact on energy metabolism, function of the liver and kidneys, metabolism of fatty acids and caused harm to DNA in rats (Dong et al., 2017). The mass of the liver of mice exposed to polyethylene and polyvinyl chloride did not reliably differ from the animals of the control group, while in mice exposed to polysterene, a significant increase in the mass of the liver by $24.0 \%$ was observed.

Plastifiers in the content of plastic cause damage to the brain tissues. In experiments on muscles of animals given peroral introduction of diisononylphthalat (DINP), oxidative stress, inflammatory reactions, apoptosis and pathologic changes in the hippocampus were observed (Peng, 2015). In chronic studies of high doses of DINP in rodents, de- 
crease in body weight, increase in mass of the liver and changes in histopathology of hepatocytes (hypertrophy) were observed. Prolonged impact of high doses of this substance even caused increase in frequency of tumours of the liver (adenoma and carcinoma) (Chen et al., 2016).

Polyethylene is one of the safest types of plastic, and is broadly used in medicine and cosmetology. Cellular and tissue reactions to polyethylene, which are determined as a part of testing biocompatibility of implants, included accumulation of fibrous connective tissue around the material of the implant. Analysis of proliferation of osteoblasts and synthesis of collagen demonstrated reduction of these characteristics depending on the influence of particles of polyethylene; intensity of this reduction is inversely proportional to the size of the particles. However, particles of polyurethane had a stimulating effect on macrophages which derived from monocytes, prolonging the survival of these cells in the culture (Anon, 2007). Our studies revealed significant increase in the number of monocytes in the blood per unit of its volume in all three experimental groups of animals, which was significantly higher than the physiological norm. Perhaps, this is related to activization of the monocytic-macrophage system of the organism as a result of introduction of microparticles of plastic through the digestive and respiratory system into the organism of mice.

The collected data indicate a relationship between the impact of substances contained in plastic (bisphenol A, phthalates) and unfavourable effects on the health of animals and humans, including cardio-vascular diseases. Epidemiological studies revealed positive correlation between their influence and chronic heart disease, hypertonia, atherosclerosis and myocardial infarction (Posnack, 2014). Many in vitro studies found a negative effect of phthalates on the function of cardiomycetes, which manifested in reduction of conductivity beginning 24 hours after exposure, and asynchronous decrease of cells after 3 day treatment (Gillum et al., 2009).

\section{Conclusions}

Polyvinyl chloride can be a factor that reduces intensity of growth of body weight of mice, perhaps as a result of slowing the energy metabolism in cells of the parenchymal organs following notable dystrophic processes. Polyvinyl chloride and polystyrene have an immune-supressive effect. Polyvinyl chloride has a negative effect both on central and peripheral lymphoid organs, causing processes of accidental involution of the thymus and hypoplasia of the lymphoid tissue of the spleen. Polystyrene affects mosly peripheral lymphoid organs, perhaps similarly to an immunosuppressive drug, which slows the processes of clonal antigendependant proliferation of lymphocytes.

All types of plastic used in the experiment cause development of leukocytopenia, which was especially manifested when polyethylene and polystyrene were used in the litter for mice and is a result of inhibition of the blood-forming potential of the bone marrow and reduction of non-specific reactivity of the organism. Increase in the amount of band neutrophils and monocytes against the background of leukocytopenia is a consequence of damage to biological barriers due to development of immune suppression and dystrophic changes in the parenchymal organs with penetration of microorganisms from the tubular and cavernous organs into the internal environment of the organism.

Increase in the mass of parenchymatous organs, the kidneys, when polyvinyl chloride is used and the kidneys and liver simultaneously when polysterene is used is conditioned by the development of parenchymal dystrophy in these organs as a result of the systemic toxic influence of different types of plastic. An intensifying factor in this process can be damage to the barriers of mucous membranes by polyvinyl chloride and polystyrene, which caused mass penetration of autotoxins from the intestine to the internal environment of the organism. This is indicated by steep increase in activity of aspartate- and alanine aminotransferase in the blood of mice in all three experimental groups. These changes are the main markers of condition of the parenchyma of the liver and myocardium (above all indicators of such pathologies as parenchymal hepatitis, and also miocardiodystrophy). Simultaneous reduction of activity of alkaline phosphatase in the blood serum of mice indicates that degenerative processes in the parenchyma of the liver and in the myocardium turn from compensatory state to the stage of decompensation, which could be related to the beginning of the development of irreversible pathological changes - cirrhosis and decompensated miocardiodystrophy. Liver "decompensation" is indicated also by the manifested reduction in the content of cholesterol and glucose in the blood serum, which are the main markers of the condition of the parenchyma of these organs.

Reduction of globulins and creatinine in the blood serum of animals of all experimental groups is a sign of the development of manifested nephropathy or tubular nephrosis, which can indicate a certain role of polyvinyl chloride, polystyrene and polyethylene in the processes of degeneration of the epithelium of uriniferous tubules.

Further studies would be promising on determining histological, histochemical and immune-histochemical changes in the organs of laboratory animals exposed to polyvinyl chloride and other types of plastic in conditions of laboratory experiment.

This work was supported by the Ministry of Education and Science of Ukraine (grants 0118U003303).

\section{References}

Al-Khatim, A.-S. A., \& Ali, K. E.-T. (2006). Effects of chemical migrants from two widely used plastics on reproduction in mice. Journal of Health Science, 52(4), 397-405.

Andrady, A. L., \& Neal, M. A. (2009). Applications and societal benefits of plastics. Philosophical Transactions of the Royal Society B: Biological Sciences, 364(1526), 1977-1984.

Boyko, A. A., \& Brygadyrenko, V. V. (2017). Changes in the viability of the eggs of Ascaris suum under the influence of flavourings and source materials approved for use in and on foods. Biosystems Diversity, 25(2), 162-166.

Chen, H., Zhang, W., Rui, B., Yang, S., Xu, W., \& Wei, W. (2016). Di(2-ethylhexyl) phthalate exacerbates non-alcoholic fatty liver in rats and its potential mechanisms. Environmental Toxicology and Pharmacology, 42, 38- 44.

Chiellini, F., Ferri, M., Morelli, A., Dipaola, L., \& Latini, G. (2013). Perspectives on alternatives to phthalate plasticized polyvinylchloride in medical devices applications. Progress in Polymer Science, 38(7), 1067-1088.

Derraik, J. G. (2002). The pollution of the marine environment by plastic debris: A review. Marine Pollution Bulletin, 44(9), 842-852.

Dong, X., Zhang, Y., Dong, J., Zhao, Y., Guo, J., Wang, Z., Liu, M., Na, X., \& Wang, C. (2017). Urinary metabolomic profiling in rats exposed to dietary di(2-ethylhexyl) phthalate (DEHP) using ultra-performance liquid chromatography quadrupole time-of-flight tandem mass spectrometry (UPLC/Q-TOFMS). Environmental Science and Pollution Research, 24(20), 16659-16672.

Dudnik, A. E., Chepurnenko, A. S., \& Litvinov, S. V. (2017). Determining the rheological parameters of polyvinyl chloride, with change in temperature taken into account. International Polymer Science and Technology, 44(1), 43-48.

Eriksen, M., Lebreton, L. C. M., Carson, H. S., Thiel, M., Moore, C. J., Borerro, J. C., Galgani, F., Ryan, P. G., \& Reisser, J. (2014). Plastic pollution in the world's oceans: More than 5 trillion plastic pieces weighing over 250,000 tons afloat at sea. PLoS One, 9(12), 1-15.

Final report on the safety assessment of polyethylene (2007). International Journal of Toxicology, 26, 115-127.

Foster, P. M. D. (2006). Disruption of reproductive development in male rat offspring following in utero exposure to phthalate esters. International Journal of Andrology, 29(1), 140-147.

Frederiksen, H., Skakkebaek, N. E., \& Andersson, A.-M. (2007). Metabolism of phthalates in humans. Molecular Nutrition and Food Research, 51(7), 899-911.

Gillum, N., Karabekian, Z., \& Sarvazyan, N. (2009). Clinically relevant concentrations of di (2-ethylhexyl) phthalate (dehp) uncouple cardiac syncytium. Biophysical Journal, 96(3), 624a.

Halden, R. U. (2010). Plastics and health risks. Annual Review of Public Health, 31(1), 179-194.

Ho, S.-M., Tang, W.-Y., Belmonte de Frausto, J., \& Prins, G. S. (2006). Developmental exposure to estradiol and bisphenol A increases susceptibility to prostate carcinogenesis and epigenetically regulates phosphodiesterase Type 4 Variant 4. Cancer Research, 66(11), 5624-5632.

Ikezuki, Y., Tsutsumi, O., Takai, Y., Kamei, Y., \& Taketani, Y. (2002). Determination of bisphenol A concentrations in human biological fluids reveals significant early prenatal exposure. Human Reproduction, 17(11), 2839-2841.

Indumathi, D., Jayashree, S., Selvaraj, J., Sathish, S., Mayilvanan, C., Akilavalli, N., \& Balasubramanian, K. (2013). Effect of bisphenol-A on insulin signal transduction and glucose oxidation in skeletal muscle of adult male albino rat. Human and Experimental Toxicology, 32(9), 960-971.

Jayashree, S., Indumathi, D., Akilavalli, N., Sathish, S., Selvaraj, J., \& Balasubramanian, K. (2013). Effect of bisphenol-A on insulin signal transduction and 
glucose oxidation in liver of adult male albino rat. Environmental Toxicology and Pharmacology, 35(2), 300-310.

Knight, J. (2012). Approaches to understanding economic growth. In: Knight, J., \& Ding, S. (Eds.). China's Remarkable Economic Growth. Oxford Scholarship Online, Oxford. Pp. 11-23.

Koch, H. M., \& Calafat, A. M. (2009). Human body burdens of chemicals used in plastic manufacture. Philosophical Transactions of the Royal Society B: Biological Sciences, 364(1526), 2063-2078.

Kuruto-Niwa, R., Tateoka, Y., Usuki, Y., \& Nozawa, R. (2007). Measurement of bisphenol A concentrations in human colostrum. Chemosphere, 66(6), 1160-1164.

Lamontagne, N. D. (2012). Plastics and human health. Plastics Engineering, 68(10), 24-31.

Landon-Lane, M. (2018). Corporate social responsibility in marine plastic debris governance. Marine Pollution Bulletin, 127, 310-319.

Lieshchova, M. A., Tishkina, N. M., Bohomaz, A. A., Gavrilin, P. M., \& Brygadyrenko, V. V. (2018). Combined effect of glyphosphate, saccharin and sodium benzoate on rats. Regulatory Mechanisms in Biosystems, 9(4), 591-597.

Liu, X., Cao, Y. F., Ran, R. X., Dong, P. P., Gonzalez, F. J., Wu, X., Huang, T., Chen, J. X., Fu, Z. W., Li, R. S., Liu, Y. Z., Sun, H. Z., \& Fang, Z. Z. (2016) New insights into the risk of phthalates: Inhibition of UDP-glucuronosyltransferases. Chemosphere, 144, 1966-1972.

Mullainadhan, V., Viswanathan, M. P., \& Karundevi, B. (2017). Effect of Bisphenol-A (BPA) on insulin signal transduction and GLUT4 translocation in gastrocnemius muscle of adult male albino rat. The International Journal of Biochemistry and Cell Biology, 90, 38-47.

Niaounakis, M. (2017). Degradation of plastics in the marine environment. In: Niaounakis, M. (Ed.). Management of Marine Plastic Debris. Elsevier Inc. Pp. 127-142.

North, E. J., \& Halden, R. U. (2013). Plastics and environmental health: The road ahead. Reviews on Environmental Health, 28(1), 1-8.

Peng, L. (2015). Mice brain tissue injury induced by diisononyl phthalate exposure and the protective application of vitamin E. Journal of Biochemical and Molecular Toxicology, 29(7), 311-320.

Piringer, O. G., \& Baner, A. L. (Eds.). (2008). Plastic Packaging: Interactions with food and pharmaceuticals. Wiley-VCH GmbH \& Co.

Posnack, N. G. (2014). The adverse cardiac effects of di(2-ethylhexyl)phthalate and bisphenol A. Cardiovascular Toxicology, 14(4), 339-357.

Prins, G. S., Tang, W.-Y., Belmonte, J., \& Ho, S.-M. (2008). Perinatal exposure to oestradiol and bisphenol A alters the prostate epigenome and increases susceptibility to carcinogenesis. Basic and Clinical Pharmacology and Toxicology, 102(2), 134-138.

Sathyanarayana, S. (2008). Phthalates and children's health. Current Problems in Pediatric and Adolescent Health Care, 38(2), 34-49.

Seth, P. K. (1982). Hepatic effects of phthalate esters. Environmental Health Perspectives, 45, 27-34.

Silva, M. J., Barr, D. B., Reidy, J. A., Malek, N. A., Hodge, C. C., Caudill, S. P., Brock, J. W., Needham, L. L., \& Calafat, A. M. (2004). Urinary levels of seven phthalate metabolites in the U.S. population from the National Health and Nutrition Examination Survey (NHANES) 1999-2000. Environmental Health Perspectives, 112(3), 331-338.

Singh, S., \& Li, S. S. L. (2012). Bisphenol A and phthalates exhibit similar toxicogenomics and health effects. Gene, 494(1), 85-91.

Skakkebæk, N. E., Rajpert-De Meyts, E., \& Main, K. M. (2001). Testicular dysgenesis syndrome: An increasingly common developmental disorder with environmental aspects: Opinion. Human Reproduction, 16(5), 972-978.

Stahlhut, R. W., van Wijngaarden, E., Dye, T. D., Cook, S., \& Swan, S. H. (2007). Concentrations of urinary phthalate metabolites are associated with increased waist circumference and insulin resistance in adult U.S. males. Environmental Health Perspectives, 115(6), 876-882.

Sun, Y., Irie, M., Kishikawa, N., Wada, M., Kuroda, N., \& Nakashima, K. (2004). Determination of bisphenol A in human breast milk by HPLC with columnswitching andfluorescence detection. Biomedical Chromatography, 18(8), 501-507.

Vandenberg, L. N., Maffini, M. V., Sonnenschein, C., Rubin, B. S., \& Soto, A. M. (2009). Bisphenol-A and the great divide: A review of controversies in the field of endocrine disruption. Endocrine Reviews, 30(1), 75-95.

Vom Saal, F. S., \& Hughes, C. (2005). An extensive new literature concerning low-dose effects of bisphenol A shows the need for a new risk assessment. Environmental Health Perspectives, 113(8), 926-933.

Yamada, H., Furuta, I., Kato, E. H., Kataoka, S., Usuki, Y., Kobashi, G., Sata, F., Kishi, R., \& Fujimoto, S. (2002). Maternal serum and amniotic fluid bisphenol A concentrations in the early second trimester. Reproductive Toxicology, 16(6), 735-739.

Zahra, N. M., Siswanto, \& Widiyanti, P. (2018). The role of chitosan on polyvinyl chloride (PVC)-glycerol biocomposites for blood bag application. Journal of Biomimetics, Biomaterials and Biomedical Engineering, 37, 94-106. 